\title{
MANFAAT PERMAINAN BOLA BASKET UNTUK ANAK USIA DINI
}

\author{
Indra Darma Sitepu \\ Fakultas Ilmu Keolahragaan, Universitas Negeri Medan \\ pieblux@gmail.com
}

\begin{abstract}
Abstrak : Dunia anak adalah dunia bermain, dari mulai bangun tidur sampai tidur kembali yang ada dalam fikiran anak adalah bermain. Maka wajar apabila bermain merupakan salah satu prinsip dasar dalam pendidikan anak usia dini. Salah satunya prinsip permainan yang tepat untuk mengajarkan anak yakni dari aktivitas olahraga. Banyak yang bisa kita ajarkan aktivitas olahraga sejak dini, salah satunya yakni permainan Bola Basket. Bola Basket sendiri merupakan olahraga yang dimainkan secara beregu dan membutuhkan teknik khusus ketika memainkanmya. Mulai dari driblling, passing, shooting, laying up, dan berbagai teknik lainnya memberikan banyak manfaat bagi kesehatan fisik siapapun yang memain. Maka dari itu tidak salah jika memperkenalkan olahraga ini untuk anak sejak usia dini.
\end{abstract}

Kata Kunci : Permaian Bola Basket, Anak Usia Dini

\section{PENDAHULUAN}

Olahraga merupakan sebuah proses kegiatan yang sistematis untuk mendorong, membina serta mengembangkan potensi jasmani, rohani dan sosial. Olahraga merupakan sebuah wadah bagi manusia untuk mengeksplorasi pengalaman geraknya. Dengan berolahraga kita akan menjadi bugar serta kualitas hidup menjadi lebih baik, tak terkecuali pada anak usia dini. Sedini mungkin mereka harus diperkenalkan oleh aktivitas olahraga atau aktivitas jasmani walaupun itu hanya olahraga yang sifat nya tidak terstruktur seperi jalan, bersepeda, bermain lompat tali dan berlari-larian.

Oktie (2011) mengatakan bahwa Olahraga adalah salah satu aktivitas menyenangkan bagi anak dengan segudang manfaat. Jangan sia-siakan kesempatan emas untuk mengajarkan dan memperkenalkan anak pada dunia olahraga sedini mungkin. Bukan hanya manfaat kesehatan, bahkan mengajarkan anak olahraga sejak usia sekolah dasar akan memberikan keterampilan lain yang mungkin tidak dimiliki oleh anak-anak lain seusianya. Karena dengan melakukan aktivitas gerak seperti itu motorik anak akan lebih baik serta tumbuh kembang mereka menjadi optimal.

Permainan bola basket pada zaman sekarang ini banyak sekali peningkatan dan semakin banyak digemari oleh masyarakat, khususnya di Indonesia bahkan telah menjadi trend setter bagi kalangan remaja-remaja. Walaupun bola basket adalah olahraga untuk kalangan muda dengan mayoritas pemain adalah kaum pria, namun sekarang bola basket juga dimainkan oleh wanita dan anak-anak yang akan menginjak masa remaja serta dari segala usia dan ukuran tubuh bahkan oleh mereka yang cacat fisik. Dikalangan pelajar baik itu dari tingkat
Sekolah Dasar, Sekolah Lanjutan Tingkat Pertama dan Sekolah Lanjutan Tingkat Atas bahkan tingkat Mahasiswa permainan bola basket banyak digemari.

Bola basket ditemukan pada Desember 1891 oleh Dr. James Naismith, seorang anggota Sekolah Pelatihan YMCA di Springfield, Masschusetts (sekarang dikenal dengan nama Springfield College). Naismith merancang bola basket sebagai jawaban atas tugas yang diberikan oleh Dr. Luther Gulick, direktur Departemen Pendidikan Fisik, yang menugaskan untuk membentuk suatu permainan seperti sepakbola atau lacrosse yang dapat dimainkan dalam ruangan selama musim dingin (Hal Wissel, 2000:1).

Permainan bola basket memerlukan kerja sama tim dan keterampilan individu yang didalamnya terkandung unsur-unsur yang sangat diperlukan bagi pemain bola basket itu sendiri. Unsur-unsur tersebut yaitu, kekuatan, kecepatan, ketepatan, daya tahan, daya ledak, keseimbangan, dan sebagainya. Sedang untuk keterampilan skill, pemain itu sendiri harus menguasai teknik dasar dari bola basket yakni, mengoper (passing), menembak (shooting), menggiring (dribble) dan merajah (rebound). Kosasih (2008) mengatakan bahwa dewasa ini permainan bola basket menjadi olahraga yang paling berkembang pesat di dunia.

Anon (1991:198) menjelaskan tentang beberapa faktor yang mempengaruhi permainan ini, yaitu: Bola basket adalah jenis permainan yang mudah dipelajari, tetapi tidak pernah dapat dikuasai dengan sempurna, (2) Tempat bermain dapat dilakukan dilapangan berumput atau lapangan terbuka atau dalam ruangan tertutup atau gedung olahraga, (3) Masing-masing regu hanya memerlukan 
5 (lima) orang pemain, bahkan di halaman rumah dengan memasang satu ring basket di garasi atau tembok permainan ini dapat dilakukan, (4) Jenis olahraga ini menuntut perlunya melakukan latihan yang baik sekali dalam membentuk kerjasama, dan (5) Penonton dapat melihat banyak hal, melalui tembakan yang bervariasi, penguasaan bola yang mempesonakan, terobosan yang fantastik, penuh tipu daya dan silih berganti yang terjadi antara regu satu dengan lawannya.

Anak usia dini adalah individu yang sedang mengalami proses pertumbuhan dan perkembangan yang pesat bahkan dikatakan sebagai perkembangan karena usia yang tepat untuk aspek perkembangan dalam pembentukan karakter dan keperibadian dalam diri anak. Usia dini merupakan fase kehidupan yang unik dengan karateristik khas masing-masing anak, baik secara fisik, psikis, sosial emosional dan moral. Oleh karena itu, anak memerlukan pembinaan pembelajaran melalui pemberian rangsangan pendidikan untuk membantu pertumbuhan dan perkembangan jasmani dan rohani agar anak memiliki kesiapan dalam memasuki pendidikan lebih lanjut dan anak tidak kehilangan kesempatan dan momentum penting dalam tumbuh kembangnya yang berlangsung. Dan mengingat anak usia dini adalah anak yang berada pada rentang usia lahir sampai enam tahun merupakan rentang usia kritis sekaligus proses pendidikan yang dapat mempengaruhi kegiatan pembelajaran tercapai secara optimal.

Menyiapkan anak untuk berolahraga pada umumnya memberi mereka semangat akan suatu keberhasilan dan kegembiraan dalam kehidupan berolahraga (Vic Ambler, 2000:8). Permainan bola basket haruslah diperkenalkan sejak usia dini, karena pada masa anak-anak pertumbuhan fisik maupun mentalnya sudah matang. Pertumbuhan yang tampak jelas adalah pertumbuhan panjang lengan dan kaki, koordinasi antara tangan dan mata serta kaki dan mata, bertambah baik pula. Keberanian juga lebih berkembang. Hal ini terjadi baik pada anak laki-laki maupun perempuan.

\section{PEMBAHASAN}

\section{Konsep Dasar Olahraga Bagi Anak Usia Dini}

Dalam olahraga usia dini, target yang harus dicapai anak adalah menerapkan sebaik mungkin keterampilan dan kemampuan yang sudah dilatih ke dalam pertandingan. Adalah besarnya usaha dan peningkatan pribadi yang seharusnya dihargai dan menjadi target bagi setiap anak, bukannya sematamata mencapai kemenangan dalam pertandingan. Tujuan melibatkan anak dalam aktivitas olahraga adalah sebagai pengenalan pengalaman berolahraga, meningkatkan keterampilan fisik, membangun kepercayaan diri.
Dalam masa ini, yang diperlukan anak adalah kegembiraan dalam melakukan latihan olahraga. Oleh karena itu pelatihnya tidak perlu menekankan pada penguasaan teknik atau peraturan pertandingan. Pujian atau hadiah diberikan kepada usaha yang dilakukan anak, bukan terhadap hasil akhir. Disini perlu ditanamkan perasaan "mencapai sukses" bukan hanya sebagai juara, tetapi juga sebagai partisipan (Arum, 2011). Oleh karena itu, penting sekali di masa awal ini setiap partisipan dalam suatu kejuaraan bisa mendapatkan penghargaan.

Persiapan mental dalam menghadapi pertandingan juga merupakan hal yang perlu diperhatikan. Utamanya anak perlu dibiasakan berfikir positif, diberi keyakinan bahwa dalam pertandingan nanti dirinya mampu menampilkan keterampilan yang telah dilatihnya. Idealnya, sesuai dengan pandangan hidup (filsafat) dan konsep pendidikan jasmani yang kita anut, pembinaan olahraga usia dini itu diarahkan pada pengenalan dan penguasaan keterampilan dasar suatu cabang olahraga yang dilengkapi dengan pengembangan keterampilan serta kemampuan fisik yang bersifat umum.

Dari naluri mendidiknya Ki Hajar Dewantara, mengatakan beliau sangat menyakini bahwa suasana pendidikan yang baik dan tepat adalah dalam suasana kekeluargaan dan dengan prinsip asih (mengasihi), asah (memahirkan), dan asuh (membimbing). Tiga aspek tersebut akan memberi corak bagi seorang anak terhadap prilaku (behavior), sikap (attitude) dan nilai (value). Seperti halnya teori Karl Groos, Yang teorinya bernama teori biologis mengatakan " Anakanak bermain oleh karena anak-anak harus mempersiapkan diri dengan tenaga dan pikirannya untuk masa depanya. Seperti halnya dengan anakanak binatang, yang bermain sebagai latihan mencari nafkah, maka anak manusia pun bermain untuk melatih organ-organ jasmani dan rohaninya untuk menghadapi masa depanya

Dilihat dari aspek biologis, olahraga anak usia dini masih dalam taraf mengembangkan aspek-aspek kebugaran jasmani ( menguatkan jantung, tulang dan otot ) serta merangsang tumbuh kembang anak secara optimal. Olahraga anak usia dini selayaknya dikemas menjadi suatu permainan olahraga yang selain mengembangkan aspek-aspek tersebut juga mengembangkan aspek psikososial, yaitu mengembangkan nilai-nilai diri anak secara positif, menuju pembangunan karakter yang sportif, dinamis, kreatif, penuh toleransi, jujur, dan bertanggung jawab.

Ahli kesehatan sepakat bahwa olahraga dapat meningkatkan kebugaran jasmani yang ditandai dengan meningkatnya fungsi jantung, pembuluh darah, sirkulasi darah, sistem pernafasan dan proses metabolisme, serta kemampuan tubuh untuk menangkal bermacam- macam penyakit baik yang disebabkan oleh infeksi maupun bukan karena 
infeksi. Olahraga juga dapat mengurangi gejala gangguan psikis, misalnya tekanan jiwa (stress) dan ketegangan jiwa (anxiety). Dengan melakukan aktivitas olahraga yang menantang, apabila seseorang mampu mengatasi tantangan tersebut, akan muncul suatu kepuasan, dan rasa puas ini akan mengurangi ketegangan jiwa.

\section{Permainan Bola Basket}

Permainan bola basket berkembang pesat sejak pertama kali diciptakan pada akhir abad ke- 19 (1891) oleh Dr. James Naismith. Permainan bola basket adalah permainan tim yang di mainkan oleh masing-masing 5 orang dalam suatu permainan. Adapun tujuan permainan ini adalah setiap regu berusaha untuk dapat memasukkan bola sebanyakbanyaknya ke dalam keranjang lawan dan menjegah pihak lawan memasukkan bola kedalam keranjangnya serta mendapatkan bola. Bola dapat dilemparkan, digelindingkan, dipantul-pantulkan, dan didorong sesuai dengan peraturan. (Aip Syarifudin dan Muhadi: 1991).

Lebih lanjut Jhon Oliver (2007:7) mengatakan bola basket adalah satu olahraga paling popular didunia. Dalam permainan bola basket setiap tim memiliki lima pemain dilapangan. Tiga angka diberikan untuk setiap bola masuk yang dicetak dari luar garis tiga angka, dua angka diberikan oleh setiap bola masuk yang dicetak dari dalam garis tiga angka, dan satu angka diberikan untuk setiap tembakan bebas. Setiap pertandingan dibagi menjadi empat quarter yang masing-masing berlangsung selama 8-12 menit atau dibagi menjadi dua babak yang masing-masing berlangsung 20 menit. Setiap pemain diizinkan untuk melakukan sebanyak - banyaknya 5 kesalahan, jika seorang pemain dilanggar saat melakukan tembakan, dia diberi dua tembakan bebas (atau tiga kalau dia saat itu sedang melakukan tembakan bebas tiga angka).

Lapangan bola basket adalah berbentuk empat persegi panjang. Bagian-bagian lapangan bola basket adalah lapangan utama, daerah tembakan hukuman, papan pantul, penyangga dan keranjang. Untuk kelengkapan permainan, ukuran bola basket pun ditentukan. Untuk ukuran standar :

1. Lapangan Bola Basket: 28 meter x 15 meter. Ukuran ini dihitung dari batas garis sebelah dalam. Di bagian tengah lapangan, terdapat lingkaran dengan jari-jari 1,80 meter. Untuk ukuran lingkaran, jari-jarinya diukur dari sebelah luar garis lingkaran.

2. Garis Tembakan Hukuman. Garis tembakan ini berada di daerah bersyarat. Ukuran daerah ini dapat dilihat pada

3. Papan Pantul Papan pantul terbuat dari kayu atau bahan lain yang sifatnya sama, tebal papan ini 3 cm. Ukuran papan pantul 1,80 meter x 1,20 meter. Di tengah papan pantul terdapat garis bingkai empat persegi panjang dengan ukuran 0,59 meter $\mathrm{x} 0,45$ meter.

4. Tiang Penyangga. Tiang penyangga atau simpei terbuat dari besi dengan garis tengah $20 \mathrm{~mm}$. Simpei berdiri dengan ketinggian dari atas lantai 3,03 meter.

5. Bola Basket. Bola basket terbuat dari karet dan dilapisi bahan sintetis Keliling bola antara $75 \mathrm{~cm}$ s.d. $78 \mathrm{~cm}$, dan beratnya antara 600 gram s.d. 650 gram.
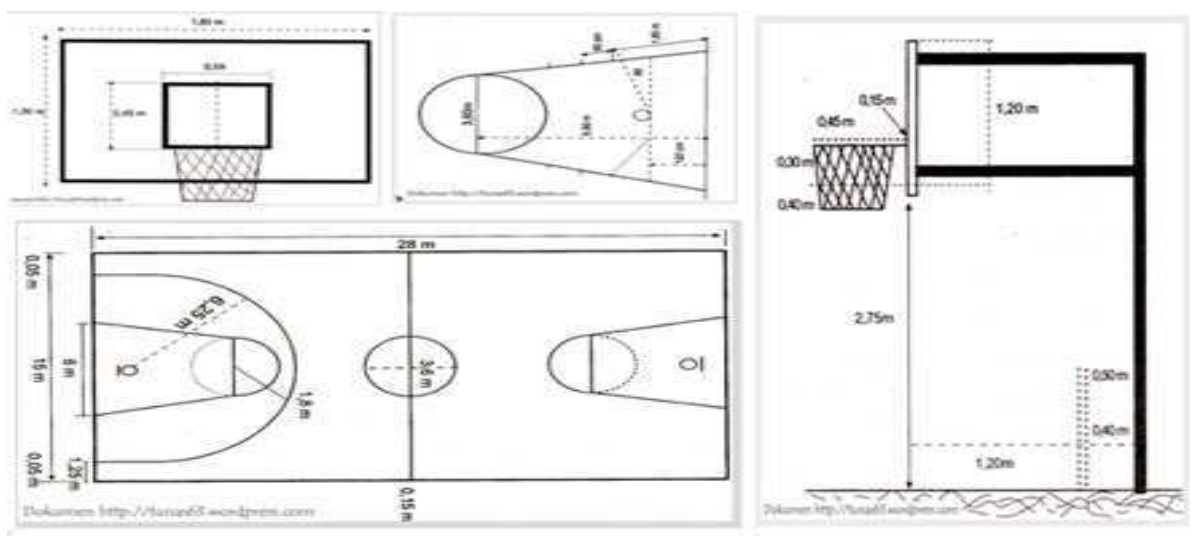

Gambar 1. Spesifikasi Lapangan Bola Basket

Untuk anak usia dini ada beberapa perubahan / modifikasi yang perlu dilakukan, yakni :

1. Tinggi ring : jika untuk pemain professional tinggi ring 3,05 meter, maka untuk anak digunakan 1,25 meter.
2. Bola : jika pemain professional menggunakan bola ukuran 7, maka untuk anak digunakan bola ukuran 5.

3. Jumlah pemain, dan peraturan permainan, dapat disesuaikan dengan lingkungan serta tingkat perkembangan anak. 


\section{Manfaat Permainan Bola Basket}

Menurut Bruner dan Suton-Smith dalam Slamet Suyanto (2005) menyatakan bahwa bermain merupakan proses berfikir secara fleksibel dan proses pemecahan masalah. Sigmund Freud mengemukakan bahwa "Bermain merupakan sesuatu yang serius bagi anak-anak, di dalam bermain anak menumpahkan seluruh perasaannya, bahkan mampu mengatur "dunia dalamnya" agar sesuai dengan "dunia luarnya". Jean Piaget mengemukakan bahwa "Melalui bermain, anak belajar mengontrol gerakannya menjadi terkoordinasi”.

Telah disadari oleh manusia bahwa bermain merupakan kegiatan yang menyenangkan dan sangat bermanfaat, kegiatan bermain bagi anak-anak sangat penting untuk penyesuai diri terhadap lingkungan hidupnya, meskipun pada masa anak-anak bermain dilakukan karena dorongan naluri tanpa disadari untuk apa mereka melakukannya (Matakupan, 1995). Unsur gerak yang dilakukan pada saat bermain bermanfaat untuk merangsang perkembangan fisik dan mental anak, karena pada masa anak-anak merupakan masa yang penting dalam memperbaiki dan menyelaraskan gerakan dasar untuk menopang kemampuan motoriknya.

Olahraga adalah suatu kegiatan yang begitu bermanfaat bagi kesehatan dan tubuh manusia. Tak jarang, berolahraga pun selalu menjadi hobi bagi mereka yang sangat mementingkan kesehatan dan tubuh. Dari sekian banyak jenis olahraga, olahraga basket adalah olahraga yang kerap kali menjadi pilihan untuk dilakukan khususnya bagi anak muda. Permainan bola basket memang dikenal dapat menyehatkan tubuh seperti halnya permainan olahraga lainnya. Tak hanya itu, permainan bola basket kerap disebut sebagai salah satu permainan olahraga yang dapat membantu anak tumbuh tinggi secara optimal.

Manfaat kesehatan dari berolahraga sejak kecil antara lain adalah:

1. Menurunkan risiko obesitas atau kelebihan berat badan.

2. Meningkatkan kebugaran anak. Saat berolahraga, jantung dan paru-paru anak akan bekerja lebih aktif sehingga fungsi kedua organ tersebut akan semakin efektif.

3. Memicu pertumbuhan tulang dan otot anak.

4. Meningkatkan koordinasi gerak dan keseimbangan tubuh.

5. Mencegah anak dari penyakit metabolik yang disebabkan oleh kurangnya aktivitas fisik.

6. Membentuk postur tubuh anak yang ideal.

7. Memberikan kebiasaan hidup aktif sehingga ketika dewasa anak-anak lebih cenderung tertarik untuk hidup aktif berolahraga. (Djauhar, 1990)
Di samping manfaat kesehatan, keuntungan sosial dan psikologis jika anak sudah aktif berolahraga sedini mungkin yaitu:

1. Membuat anak semakin terasah mendengarkan dan mengikuti instruksi.

2. Membantu anak belajar memimpin, bekerjasama, dan menjadi bagian dalam satu tim.

3. Membuat anak paham artinya menang dan kalah adalah hal yang biasa.

4. Meningkatkan kemampuan akademik anak. Olahraga membutuhkan penghafalan, pengulangan, dan pembelajaran sehingga otak anak akan lebih aktif.

5. Meningkatkan kemampuan sosial anak. Bergabung dengan tim olahraga akan memberikan anak kesempatan bertemu dan menjalin relasi dengan orang-orang baru.

6. Meningkatkan kedisiplinan anak. Jadwal latihan, tiap instruksi yang diberikan akan membentuk kedisiplinan anak.

Berikut adalah manfaat permainan bola basket secara umum :

1. Menyehatkan dan menyegarkan badan

Yang pertama dari manfaat berolahraga basket yaitu menyehatkan dan menyegarkan badan. Ketika sedang berolahraga basket, otomatis tubuh akan membuang energi sisa selama beraktifitas berupa cairan keringat, kemudian diganti dengan energi baru. Energi baru tersebut berupa makanan dan minuman yang sehat, yang dikonsumsi setelah beberapa menit melakukan olahraga basket. Hal ini akan membuat tubuh terasa segar dan fit untuk memulai aktiftas baru.

2. Melatih daya pacu jantung

Ketika melakukan olahraga basket, pacu detak jantung akan semakin cepat dan berdetak normal kembali ketika istirahat. Hal ini baik bagi kesehatan tubuh karena peran jantung dalam tubuh mengedarkan darah ke semua tubuh.

3. Melancarkan peredaran tubuh

Manfaat yang ketiga berhubungan dengan poin yang kedua. Saat daya kerja detak jantung yang baik, maka peredaran darah dalam tubuh pun akan baik. Hal ini mencegah berbagai macam masalah tubuh yang timbul, seperti pusing, stroke, keram, kesemutan, dan lain sebagainya.

4. Mempercepat pertumbuhan tubuh

Kegiatan olahraga basket, apapun bentuknya dengan catatan sesuai dengan kemampuannya, berperan mempercepat pertumbuhan tubuh seperti tinggi badan dan bentuk otot tubuh

5. Mengurangi risiko terkena penyakit jantung Saat berolahraga basket, otomatis tubuh membakar lemak dan kolesterol. Dengan pembakaran lemak dan kolesterol dalam tubuh, mengurangi risiko terkena penyakit jantung yang biasanya dialami pria dan wanita yang 
sudah berumur. Akan tetapi banyak kasus sekarang para remaja maupun baru beranjak dewasa yang sudah memiliki penyakit jantung. Untuk itu, disarankan berolahraga lah sejak dini.

6. Membakar Kalori

Kalori tubuh yang diperoleh dari berbagai sumber salah satunya adlah makanan memang harus diproses atau dibakar untuk dijadikan energi karena apabila kalori tidak diproses akan dapat mempengaruhi kondisi kesehatan tubuh anda.

7. Membangun serta melatih koordinasi tubuh Membangun koordinasi tubuh serta melatihnya pada awalnya adalah hal yang sulit karena tubuh belum seimbang atau balance, olahraga basket sangat membantu hal ini karena sangat bagus untuk siswa ataupun anak yang akan membangun keseimbangan saraf-saraf motorik pada tubuh.

8. Melatih Ketangkasan

Ketangkasan tubuh bisa dilatih melalui olahraga ini karena olahraga basket akan mengajarkan kita untuk tangkas dalam melakukan berbagai gerakan yang lincah, aerobic dan natural yang bias dikombinasikan dengan berbagai gaya.

9. Menambah Tinggi Badan

Tinggi badan yang ideal adalah dambaan semua orang karena hal ini sangat mempengaruhi kepercayaan serta sifat pribadi seseorang apabila ada ditempat umum.Olahraga ini adalah yang paling baik untuk membantu untuk meraih tinggi badan yang diinginkan.

10. Menambah Daya Imunitas Tubuh

Sistem ketahanan tubuh atau imunitas sangat berguna untuk mencegah bakteri dan virus yang bersifat patogen masuk atau menyerang tubuh yang sedang dalam keadaan yang lemah, oleh karena itu sistem imunitas harus dilatih dengan berolahraga salah satunya adalah olahraga basketball atau bola basket.

11. Meningkatkan Konsentrasi Belajar dan Bekerja Konsentrasi sangat diperlukan dalam bekerja karena akan mempengaruhi hasil yang diperoleh setelah melalui proses yang panjang, oleh karena itu konsentrasi tubuh perlu dijaga dan ditingkatkan guna memperoleh hasil yang lebih baik.

12. Bola Basket Baik Untuk Keseluruhan Tubuh Berlari, melompat dan menggiring bola yang melibatkan otot lurik dan dada sangat untuk membangun keseluruhan kesehatan tubuh. Selain itu, aktivitas melompat juga sangat baik untuk membangun otot kaki.

13. Cara lain untuk Menurunkan Berat Badan Olahraga bola basket sangat luar biasa dalam memfasilitasi penurunan berat badan seseorang. Kondisi itu bisa terjadi karena aktivitas permainan yang melibatkan dribbling, passing, melompat dan berlari itu membantu menurunkan lemak ekstra dalam tubuh. Satu jam dari permainan bola basket bias membantu membakar kalori sekira 700 sampai 750 kalori.

14. Meningkatkan Kekuatan Otak

Dibutuhkan tingkat konsentrasi yang baik untuk bisa bermain olahraga bola basket. Mata pemain harus fokus pada bola yang bergerak cepat dari pemain ke pemain. Hal itulah yang akhirnya merangsang otak sehingga bias meningkatkan fungsi otak seseorang.

15. Membantu Kadar Hormon

Wanita muda yang menderita disfungsi hormon disarankan untuk bermain basket secara teratur. Peregangan dan melompat selama pertandingan menyebabkan otot perut menguat, dan menyetabilkan metabolisme yang membantu dalam mengatur masalah hormonal wanita.

16. Membantu menghindari obesitas dan osteoporosis

Masalah seperti obesitas dan osteoporosis bisa dihindari dengan bermain basket. Hal itu karena basket tak hanya membangun daya tahan tubuh, tapi juga meningkatkan keseimbangan tubuh.

17. Basket untuk Bersenang-senang

Dimanapun mereka berada, mereka melakukan berbagai hal dengan kesenangan dan kegembiraan. Bermain bersama, mengembangkan strategi permainan dan membentuk ikatan antar teman sebaya pastinya akan menjadi aktivitas yang menyenangkan bagi para remaja.

Sedangkan untuk anak-anak, manfaat permainan bola basket yang akan mereka terima antara lain :

1. Membangun fisik anak.

Bermain basket melibatkan tubuh bergerak dan berkoordinasi sehingga kekuatan dan daya tahan tubuh anak dapat terlatih dengan sempurna. Olahraga basket sangat bermanfaat bagi kesehatan anak karena banyak melibatkan aktivitas berlari dan melompat sehingga anak dapat mengembangkan kekuatan fisik, kecepatan dan bahkan kesehatan jantung. Selain itu, bermain basket akan membakar kalori dalam jumlah yang cukup banyak. Pola gerakan dalam basket juga mengajarkan anak untuk cepat berkoordinasi dan melatih memori kinestetiknya. Dengan bermain basket anak secara alami lebih aktif, kuat, dan terampil.

2. Melatih Ketangkasan

Bila menginginkan anak bergerak dengan lincah, permainan basket dapat melatih ketangkasan anak. Disini olahraga basket akan mengajarkan anak untuk tangkas dalam melakukan berbagai gerakan yang lincah, aerobic dan natural yang bisa dikombinasikan dengan berbagai gaya. 
3. Memaksimalkan Pertumbuhan

Olahraga basket merupakan salah satu olahraga pilihan yang cocok untuk anak-anak yang tengah dalam masa pertumbuhan, karena aktivitas olahraga yang satu ini bisa memaksimalkan pertumbuhan. Peningkatan tinggi badan yang lebih optimal dapat diperoleh berkat latihan basket yang dilakukan secara rutin dan berkala. Fisik yang sehat dan pertumbuhan yang maksimal bisa dirasakan oleh siapa saja yang menjadi basket sebagai salah satu olahraga yang diterapkan.

4. Meningkatkan Konsentrasi dan Fungsi Otak Basket merupakan salah satu jenis permainan olahraga yang bukan hanya mengandalkan tenaga atau kekuatan fisik semata, namun juga membutuhkan konsentrasi dan kemampuan berpikir untuk menyusun strategi penyerangan ke area lawan. Melakukan pergerakan tangan dan kaki dalam setiap teknik bermain basket juga memerlukan fokus atau koordinasi yang baik agar tidak terkena pelanggaran. Dengan kata lain, manfaat olahraga basket membuat anak lebih efektif dalam melatih fungsi dan meningkatkan kinerja otaknya.

5. Mengajarkan anak bersosialisasi

Permainan basket adalah permainan tim dan bukan permainan individu. Dasar dari bermain basket adalah mengoper bola. "Kita tidak bisa mengoper bola pada diri sendiri, kita harus memberikannya pada rekan satu tim," ujar Stephen L. Metcalfe, yang akrab disapa Met, pendiri Karawaci Youth League Sports di Karawaci, Tangerang. "Ide keseluruhan dari permainan basket adalah bekerja sama untuk mencapai satu tujuan," lanjut Met. Dengan bekerja sama dalam satu tim, anak-anak dapat membentuk rasa hormat pada rekan sepermainannya dan mengembangkan kemampuan bersosialisasi mereka.

6. Baik untuk Perkembangan Mental

Bermain basket dapat meningkatkan rasa percaya diri anak. Saat anak berhasil memasukkan bola ke dalam keranjang, akan timbul kebanggaan dalam diri anak yang kemudian membuatnya lebih percaya diri. Selain itu, permainan basket juga akan meningkatkan kemampuan otak pada anak saat mereka berusaha memahami strategi permainan basket seperti offence (menyerang) dan defence(bertahan).

7. Membuat Anak Lebih Percaya Diri

Jika sedari kecil sudah dibiasakan untuk berlatih olahraga, sedikit demi sedikit kepercayaan dirinya akan terbangun, salah satunya bisa melalui basket. Apalagi jika mereka suka mengikuti pertandingan dan tidak jarang memenangkannya, maka kepercayaan diri mereka akan semakin bertambah. Anak-anak juga bisa jadi lebih senang membuat prestasi melalui olahraga yang disukainya.

8. Basket untuk Bersenang-senang

Dimanapun mereka berada, anak-anak tetaplah anak kecil. Mereka melakukan berbagai hal dengan kesenangan dan kegembiraan. Bermain bersama, mengembangkan strategi permainan dan membentuk ikatan antar teman sebaya pastinya akan menjadi aktivitas yang menyenangkan bagi si kecil.

Selain membantu kesehatan tubuh dan tumbuh kembang anak, permainan bola basket juga dapat mengembangkan beberapa kecerdasan anak, seperti :

1. Kecerdasan Kinestik-Jasmani

Setiap permainan bola basket dituntut untuk mampu melakukan gerakan-gerakan dari memantulkan bola, berjalan atau berlari menggiring bola, hingga melepar bola ke ring. Gerakan tersebut menuntut koordinasi motorik tangan dan kaki anak sehingga ia terlatih mengendalikan gerak tubuhnya dan menangani bola yang sedang dalam pegangannya.

2. Kecerdasan Interpersonal

Permainan bola basket yang dilakukan berkelompok akan melatih kemampuan anak untuk memahami motivasi dan kepribadian orang lain. Selain itu, anak juga dapat mempelajari bagaimana cara menghadapi dan menyesuaikan diri dengan setiap individu yang ada di dalam tim basketnya.

3. Kecerdasan Visual-Spasial

Saat bermain bola basket anak dituntut untuk dapat memahami lapangan dan posisi setiap individu di lapangan dalam formasi. Sehingga anak dengan cepat mampu mengarahkan tubuhnya guna mencapai ring. Dibutuhkan pula kemampuan untuk menganalisa ketepatan melempar bola ke ring, dimana anak harus mampu memperkirakan jarak dirinya dengan ring secara keruangan. Bahkan anak butuh representasi visual dalam pikirannya tentang bagaimana bola mausk ke ring sehingga mampu memperkirakan seberapa kuat dia perlu melempar bola ke ring agar bisa masuk dan mencetak angka.

4. Kecerdasan Logis-Matematik

Anak dituntut untuk memahami berbagai strategi permainan dari bertahan, menyerang, melempar, dan sebagainya. Strategi ini dapat mengasah kemampuan anak untuk mempelajari pola permainan secara logis berdasarkan penalaran.

5. Kecerdasan Moral

Anak belajar untuk memahami dan mematuhi aturan permainan, Walaupun tidak harus secara kaku dan keras, tetapi paling tidak anak tahu aturan-aturan dasar permainan ini. 


\section{KESIMPULAN}

Dunia anak adalah dunia bermain, dari mulai bangun tidur sampai tidur kembali yang ada dalam fikiran anak adalah bermain. Maka wajar apabila bermain merupakan salah satu prinsip dasar dalam pendidikan anak usia dini. Salah satunya prinsip permainan yang tepat untuk mengajarkan anak yakni dari aktivitas olahraga. Banyak yang bisa kita ajarkan aktivitas olahraga sejak dini, salah satunya yakni permainan Bola Basket.

Bola Basket sendiri merupakan olahraga yang dimainkan secara beregu dan membutuhkan teknik khusus ketika memainkanmya. Mulai dari dribbling, passing, shooting, lay up, dan berbagai teknik lainnya memberikan banyak manfaat bagi kesehatan fisik siapapun yang memain. Maka dari itu tidak salah jika memperkenalkan olahraga ini untuk anak sejak usia dini. Selain membantu kesehatan tubuh dan tumbuh kembang anak, permainan bola basket juga dapat mengembangkan beberapa kecerdasan anak.

\section{REFERENSI}

Anon, 2000. Peraturan Permainan Bola Basket Mini. Jakarta: Dirjen PLS Pemuda dan Olahraga.

Arum, Yuli. 2012 .Peran olahraga bagi anak usia dini http://olah-raga indonesia. blogspot.com /2012/05/peran-olahraga-bagi-anak-usia dini. html.
Djauhar, Ismail. 1990. Tumbuh Kembang Anak: Kursus Penyegaran IDAI cabang Yogyakarta. Yogyakarta: Fakultas Kedokteran UGM.

Kosasih, Danny. 2008. Fundamental Basketball. Penerbit : Karmedia

Matakupan, J. 1995. Teori Bermain. Jakarta: Depdikbud.

Nuril Ahmad. 2007. Permainan Bolabasket. Era Intermedia. Solo.

Sodikun, Imam. 1992. Olahraga Pilihan Bola basket. Surakarta: Cetakan Pertama. Era Intermedia.

Steven, Oktie. 2011. Olahraga untuk anak. http://oktieseven.wordpress.com/olahragauntuk-anak/

Sugiyanto. 1993. Pertumbuhan dan Perkembangan Gerak. Jakarta: Pusat Pendidikan dan Penataran KONI Pusat.

Sumiyarsono, Dedy. 2002. Keterampilan bola basket. Surakarta: Yudhistira.

Wissel, Hal 1996. Bolabasket: Langkah untuk sukses (Bagus Pribadi. Terjemahan). Jakarta: PT Raja Gravindo Persada. Buku asli diterbitkan Tahun (1994). 